how the hypothesis may be of value in understanding the functioning of the higher parts of the central nervous system.

${ }^{1}$ Eccles, J. C., Nature, 158, 680 (1945).

Eccles, J. C., Ann. N.Y. Acad. Sci., 47, 429 (1946).

-Lloyd, D. P. C., J. Neurophysiol., 9, 421 (1946).

4Lloyd, D. P. C., J. Neurophysiol., 9, 439 (1946).

'Renshaw, B., J. Neurophysiol., 3, 373 (1940).

- Renshaw, B., J. Neurophysiol., 5, 487 (1942).

"Lloyd, D. P. C., J. Neurophysiol., 6, 111 (1943).

- Lloyd, D. P. C., J. Neurophysiol., 6, 293 (1943).

- Lloyd, D. P. C., J. Neurophysiol., 6, 317 (1943).

${ }^{10}$ Eccles, J. C., J. Neurophysiol., 9, 87 (1946).

" Cajal, S. R., "Histologie du système nerveux de l'homme et des vertébrés" (Paris, Maloine, 1909), 1.

12 Lloyd, D. P. C., J. Neurophysiol., 4, 184 (1941).

${ }^{1 s}$ Lloyd, D. P. C., Physiol. Rev., 24, 1 (1944).

14 Renshaw, B., Amer. J. Physiol., 146, 443 (1946).

15 Bernhard, C. G., J. Neurophysiol., 7, 397 (1944).

10 Hughes, J., and Gasser, H. S., Amer. J. Physiol., 108, 295 (1944)

${ }^{17}$ Gasser, H. S., Harv. Lect., 32, 169 (1937).

${ }^{18}$ Hughes, J., McCouch, G. P., and Stewart, W. B., Amer. J. Physiol., 118, 411 (1937).

19 Lorente de Nó, R., J. Neurophysiol., 1, 207 (1938).

${ }^{20}$ Bremer, F., and Bonnet, V., Arch. Int. Physiol., 52, 153 (1942).

${ }^{21}$ Sherrington, C. S., Proc. Roy. Soc., B, 97, 519 (1925).

${ }^{22}$ Eccles, J. C., and Sherrington, C. S., Proc. Roy. Soc., B, 109, 91 (1931).

ss Creed, R. S., Denny-Brown, D., Eccles, J. C., Liddell, E. G. T., and Sherrington, C. S., "Reflex Activity of the Spinal Cord" (Oxford, 1932).

24 Barron, D. H., and Matthews, B. H. C., J. Physiol., 85, 73 (1935).

${ }^{2 s}$ Barron, D. H., and Matthews, B. H. C., J. Physiol., 92, 276 (1938).

${ }^{86}$ Gerard, R. W., Ohio J. Sci., 71, 160 (1941).

${ }^{27}$ Bodian, D., Physiol. Rev., 22, 146 (1942).

${ }^{26}$ Gesell, R., and Hansen, E. T., Amer. J. Physiol., 144, 126 (1943).

29 Brooks, C. McC., and Eccles, J. C., in the press.

${ }^{\text {so }}$ Barr, M. L., J. Anat., 74, 1 (1939).

21 Eccles, J. C., J. Neurophysiol. (May, 1947).

"Lorente de Nó, R., R. Prychol. Neurol., Lpz., 45, 381 (1934).

${ }^{23}$ Lorente de N6, R., J. Cell. Comp. Physiol., 7, 47 (1935).

s Brooks, C. McC., and Eccles, J. C., sent for publication in $J$. Neurophysiol.

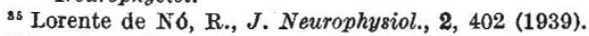

${ }^{36}$ Renshaw, B., J. Neurophysiol., 5, 235 (1942).

s7 Lloyd, D. P. C., J. Neurophysiol., B, 143 (1943).

${ }^{88}$ Hodgkin, A. L., Proc. Roy. Soc., B, 126, 87 (1938).

so Bremer, F., Bonnet, V., and Moldaver, J., Arch. Int. Physiol., 52, 1 (1942).

${ }^{40}$ Lloyd, D. P. C., J. Neurophysiol., 4, 525 (1941).

4 Lloyd, D. P. C., J. Neurophysiol., 5, 435 (1942).

${ }^{22}$ Beritoff, J., Trans. J. Beritashvili. Physiol. Instit. Tiflis, 3, 21 (1937)

43 Sherrington, C. S. "TThe Integrative Action of the Nervous System" (Yale Univ. Press, 1906).

* Sherrington, C. S., Proc. Roy. Soc., B, 105, 332 (1929).

4s Sherrington, C. S., Rrain, 54, 1 (1931).

"Granit. R., "Sensory Mechanisms of the Retina" (Oxford Univ. Press, 1946).

${ }^{47}$ Lorente de N6. R., Chap. 15 in Fulton, J. F., "Physiology of the Nervous Svstem" (London, New York and Toronto, Oxford Univ Press. 1938).

¿s Blake, H., Gerard, R. W., and Kleitman. N., J. Neurophysiol., 2, 48 (1939).

\section{THE ROYAL ACADEMY, 1947}

\section{By Dr. A. TINDELL HOPWOOD}

$\mathrm{T}$ HERE are those who exhibit at the Royal Academy, and those who do not : there are those who visit the Royal Academy, and those who do not. Once the doors of the Summer Exhibition are opened, those who do either are of present importance and mutually dependent. The interplay of artist and visitor makes each new show a fresh adventure for anyone who is neither too ignorant to have acquired that sense nor so bored as to have lost it. Ignorant may seem a harsh word to use, but it is not unkindly meant. One cannot find intellectual adventure in that which one does not understand, but there is adventure in the effort necessary to understanding.
For most people the annual adventure of the Academy consists in making the effort to understand. None but a favoured few can hope to escape the necessity of effort, since there are very few who can easily understand what an artist is striving to achieve. According to Michelangelo, "Good painting is a music and a melody which only the intellect can appreciate, and that with great difficulty". The same sentiment has been repeated by successive generations of artists, among others by the Academy's first president. This, if it be true-and there can be no argument about that-makes nonsense of the claim that 'art belongs to the people' taken in its usual connotation. On the other hand, it is true that art belongs to so many of the people as are willing to make the intellectual effort necessary for its comprehension. In art, as in all other human activities, one cannot have something for nothing.

Out of nothing, nothing is made, is just as true of artists as of spectators. The latter reveal the vacant mind by their chatter, the former reveal it in their works. Every year such minds are with us, but the Hanging Committee can usually find spots where their patients may linger in comparative obscurity. Perhaps it is unfair to introduce in this way an exhibition which is so much better than its predecessor, but I do not think it is. The higher the general standard, the more obvious do the babblers become ; but it is also easier to close one's ears to their babble.

For the past fifty years there has been much noisy argument about the modern movement in art, and the modernists have shown a degree of intolerance equalled only by the intolerance of their opponents. The point at issue really boils down to whether line or colour is pre-eminent. The question is of small significance because each artist and each spectator will return that answer which best accords with his own temperament. There is no merit in denying the artistic worth of "Bol de Lait" by the late Pierre Bonnard, neither is there merit in praising it to the detriment of more academic canvases. Bonnard was a colourist and light was necessarily his primary interest. Now it is a curious thing that light, which reveals to us the planes and perspectives and all the geometry of Nature, ends by obscuring what it reveals. Turner knew this in his day, and M. Bonnard's picture is a restatement in a different idiom.

It is fitting that works by a great Frenchman should hang in the Academy, for it is from France that the moderns draw their inspiration; but one should not forget that the French themselves derive from an Englishman, John Constable, whose strivings after light were no less intense than those of Cézanne. Moreover, the inspiration from across the Channel must not blind us to the native interpretation of Constable's teaching. For this reason attention should be given to Sir Alfred Munnings' 'Frisian Bull", in which the landscape suggests that his oftexpressed affection for George Stubbs is equalled by his affection for Constable. "Sketch of a Newmarket Start", which hangs a few feet from the bull, is full of a nervous vitality vastly different from the bucolic peace of the latter, and this tends to obscure the masterly skill with which the rhythmic motion of the jockeys and their mounts is conveyed.

One of the less good positions is No. 1. It is on a reverse wall, but has the compensation that most visitors look there when they are fresh, and before their energies have begun to flag. Here hangs "Once Upon a Time" by Lilian Jelly, noteworthy for its interpretation of texture and line. On the same wall, 
"Autumn", by Dame Laura Knight, is the first of three valiant and not unsuccessful attempts at rendering atmospheric effects of great difficulty.

The same room contains several pictures by younger artists, two of whom appear for the first time : "A Yellow Dressing Table" is by Pat Newton, and "Still Life" by Henry Kilvert. There are also three flower pieces, "Autumn Flowers", by Elsie Atkins, who exhibited in 1944 and 1946 ; "Summer Flowers", by Vera Waddington, also an exhibitor in 1944 and 1946 ; and "Geraniums", by D. Travers-Smith, whose picture last year was, I think, her first. Both Miss Atkins and Miss Waddington paint flowers well, and each has shown in previous years that she is not afraid of other subjects. The arrangement of Miss Travers-Smith's geranium is rather obvious, and the design is over-emphasized by the background. Best of all is the yellow dressing-table in its garret window ; there is more originality in the subject, and more character in the painting.

One of Mr. Churchill's pictures hangs near the dressing-table. It is "Winter Sunshine", a not altogether successful sketch of a red-brick house standing in a snowy garden. The arrangement of the high lights, and the mass of shadow in the middle of the canvas, give the impression that the centre of the picture has dropped out. His other picture, said to be a later work, is in Gallery III. "The Loup River, Alpes Maritimes" is above the average in its rendering of flowing water. Taken together, they show Mr. Churchill to have considerable talent as a painter, but they display none of that robustiousness popularly associated with Mr. Churchill the politician.

If the Academy were restricted to oils, one might well stop there, for what has been said serves as a sample of the whole. As it is, there are other media to consider, and of them the water-colours in the South Rooms are easily the most important. Watercolour drawing is so essentially an English art that one is not surprised when its practitioners prove to be more consistently interesting than the painters in oils. R. Vivian Pitchforth, Barbara Jones, Hadley Rowe and Peter Lowry each has something worth saying, though Mr. Rowe should know better than to put tropical shells on what appears to be a typically English beach. Mr. Pitchforth is, of course, one of our leading water-colourists and an associate of the Academy, but Miss Jones and Mr. Rowe are, I believe, exhibiting for the first time. There is both character and individuality in their work. Mr. Lowry had pictures hung in 1945 and again last year; that he tends to dramatize his subject is not necessarily a fault. Two pictures of the shipyards at Appledore possess a maturity and sureness of touch which prove Michael Leszczyński to be much more than a beginner, even though this is the first time he has been hung in the Academy. Hal Yates" "Runswick" and Dennis James' "Snow Scene, Kingsley Way" each deserve more than a passing glance; the latter is not hung as well as it should be.

To return to the oil-paintings. Henry Hoyland has been represented by a picture or two since 1944, and, as his two studies of the circus show, he improves each year. Jean Primrose has two works of great promise in "Ballerina" and "Angela Reading", and that brings us to the Black and White Room (Gallery IX). This I found dull apart from Miss Winifred Austen's bird studies, which have a charm all their own, and Robert Austin's engravings. Sir Lionel Lindsay's dry-point is of particular interest: it throws a flood of light on his book "Addled Art".
There is little to be said about the architectural exhibits; present conditions are not kind, and architects are in partial eclipse. Neither is the sculpture very interesting. It is always difficult to make a gallery of small busts look anything but spotty, and this year the difficulties appear to have proved greater than usual.

Nevertheless, this is a 'good' Academy, and if the next can improve on it as much as this one has improved on last year's, then there will be firm reason for thinking that artists as a whole have recovered from their post-war malaise.

\section{THE ADRENAL CORTEX}

$T$ HE fourth meeting of the Society of Endocrinology, held on March 28 in the Department of Anatomy, University of Birmingham, was devoted to a discussion on the adrenal cortex. In the opening paper, entitled "Recent Advances in the Chemistry of the Adrenal Cortex", Dr. C. W. Shoppee mentioned briefly the six steroids newly isolated from adrenal tissue during the past seven years, which include œstrone, $\Delta^{4}$-androstene-3:17 dione, and 17-hydroxyprogesterone. The total number of adrenal steroids with known structures is now twenty-eight, of which six are active in preserving the life of the adrenalectomized animal. The structures of most of these compounds are completely determined. Where hydroxyl groups exist at positions 3 and 11 they are ( $\beta$ ) orientated, while hydroxyl groups at position 17 are almost certainly in the $(\alpha)$ position. During the past few years it has become clear that adrenal steroids, as well as deoxycholic acid, have the side-chain at position 17 in the $(\beta)$ position and not, as was previously believed, $(\alpha)$ orientated. Reichstein has now prepared all six physiologically active steroids artificially. The molecular features essential for high activity appear to be a 3-keto- $\Delta^{4}$-grouping, together with a $17(\beta)$ sidechain of the form $-\mathrm{CO} . \mathrm{CH}_{2} \mathrm{OH}$. For activity with respect to carbohydrate and protein metabolism, an oxygen atom at $\mathrm{C}_{11}$, either as a keto-group or a ( $\beta$ )-orientated hydroxyl group, appears to be essential.

The pure crystalline substances isolated from cortical extracts represent only a small fraction of the activity of the concentrates from which they are prepared: the greater part of the activity (about 90 per cent) remains in the so-called amorphous fraction. The latter shows somewhat anomalous physiological properties, and it is likely that there remain to be isolated one or more unknown labile compounds, probably containing five oxygen atoms, which are more active than any of the hormones yet obtained in a state of purity. Lowenstein and Zwemer (Endocrinology, 39, 63; 1946) have recently reported the isolation of 11-dehydrocorticosterone and two incompletely characterized substances, the combined activity of which equalled 80 per cent of the activity of the original concentrate. One of these compounds gave ascorbic acid by mild anaerobic hydrolysis; the other, presumably steroid, product of hydrolysis has not been isolated.

In his communication entitled "The PituitaryAdrenal Relationship", Dr. M. Reiss discussed first the problem of the isolation and biological assay of pituitary corticotrophic fractions. For assay purposes, Dr. Reiss and his colleagues have investigated the histological changes occurring in the adrenal glands of hypophysectomized rats. The sudanophilic 